\title{
Economic Sanctions: A Political, Economic, and Normative
}

\section{Analysis}

\author{
Rachael Gosnell \\ University of Maryland, Maryland, United States
}

\begin{abstract}
The use of economic sanctions as a foreign policy tool dates back to the Megarian decree of $432 \mathrm{BC}$, but has long been controversial. Economic sanctions are commonly employed by governments as a coercive tool to adjust the behavior of a state actor that is in violation of international behavior norms, yet there remains concern as to the effectiveness of applying economic sanctions and the extent to which sanctions should be applied. Further questions arise regarding both the viability and morality of sanctions. This paper will examine case studies to determine the moral, economic, and political impact of imposing sanctions on state actors. In doing so, this paper will specifically examine the economic sanctions applied to South Africa, Iran, and Crimea. It will examine the application of sanctions and the effectiveness in achieving established foreign policy goals, while also analyzing the impact on innocents to determine the ethical implications of sanctions.
\end{abstract}

Keywords: economic sanctions, foreign policy, normative analysis, economic foreign policy tools

\section{Introduction}

Since the rise of the modern Westphalian nation-state, governments have sought methods to adjust the behavior of other state actors to ensure adherence to both national and international interests. While foreign policy tools have evolved greatly over the years, coercive and cooperative efforts are still at the forefront of policy decisions. The rise of an established international order has permitted states to work cooperatively to adjust the behavior of state actors that threaten interests or violate international norms. Economic sanctions have become a heavily relied upon tool of foreign policy as states and multinational organizations seek to alter the behavior of other state actors in a globalized world, yet they remain mired in debate. Prominent questions surrounding the application of economic sanctions include not only viability-Do they actually work? But also morality-Should they be used to coerce state behavior given the potential impact on innocents?

This paper will seek to explore economic sanctions utilizing case studies to assess the moral, economic, and political impact of imposing sanctions. To determine this impact, the paper will examine different types of sanctions against state actors as a foreign policy tool and determine implications from a normative perspective. Case studies will present insights into the rationale for applying sanctions, as well as the costs of doing so viewed from both a realist and liberalist perspective. An ethical analysis will then be applied to examine the costs imposed from sanctions, with a primary focus being on sanctions applied by the US. These analyses will then be examined for broader applicability as to the moral, economic, and political viability of economic \footnotetext{
States.

Rachael Gosnell, doctoral candidate, International Security and Economic Policy, University of Maryland, Maryland, United
} 
sanctions as a foreign policy option.

The usage of economic sanctions to achieve foreign policy objectives has become an increasingly popular tool in recent years, but is not new. Hufbauer (2007) notes that sanctions date to at least 432 BC with the Megarian decree issued by Greek statesman and General Pericles who sought to strangle the Megara economy (Hufbauer, 2007). The US first administered economic sanctions prior to the War of 1812, targeting Great Britain for the harassment of American sailors. Following the German invasion of Norway in 1940, the US applied sanctions to prevent Nazi usage of occupied countries' holdings and later extended sanctions to block assets of the Axis powers while prohibiting foreign trade and financial dealings with these nations. Sanctions were employed frequently during the Cold War to destabilize governments, particularly in Latin America. Since the end of the Cold War, economic sanctions have been a widely used foreign policy tool both in the US and within the international community. This paper will later examine more recent sanctions as specific case studies, including Crimea, Iran, and South Africa to analyze the economic, political, and moral impact of economic sanctions.

It must first be established what can be defined as an economic sanction, particularly noting what does and does not fall within the scope of the policy tool. While there is some dispute as to the breadth and scope of the definition of an economic sanction, and indeed, differing governments have a range of accepted practices that may fall into the economic sanctions realm, there is a basic consensus on the broad definition. Economic sanctions can be defined as "the withdrawal of customary trade and financial relations for foreign and security policy purposes” (Masters, 2017). Hufbauer and Oegg (2003) limited the definition, stating sanctions are "deliberate, government-inspired withdrawal, or threat of withdrawal, of customary trade and financial relations". Doxey (1996) further defined international sanctions as "penalties threatened or imposed as a declared consequence of the target's failure to observe international standards or international obligations”.

From these basic definitions, it is necessary to further explore what constitutes a sanction and what falls beyond the scope of an economic sanction. While each nation-state maintains a unique definition, criteria for, and application process of economic sanctions, this paper will focus primarily on the US government and international organizations that have advocated for economic sanctions. This section will briefly explore the sanctions process for the US and the UN, with a recognition that many other countries and organizations (specifically the EU) also have significant economic sanctions programs, with differing definitions and processes.

In the US, economic sanctions originate in either the executive or legislative branches. It is important to examine the process for which sanctions may be applied in order to develop the foundation for a later discussion on the ethics of economic sanctions. Congress may pass legislation imposing sanctions or the President may draft an Executive Order declaring a national emergency in response to "an unusual and extraordinary foreign threat” (Masters, 2017). This declaration invokes special powers pursuant to the International Emergency Economic Powers Act with regard to the announced threat for a period of one year, though it may be further extended by the president or terminated by an Act of Congress. The president may also use Executive Orders to modify sanctions.

The US State Department noted that economic sanctions should encompass the "deliberate, government-inspired withdrawal, or threat of withdrawal, of customary trade or financial relations" (Office of the Spokesperson, US State Department, 2014a). Sanctions may be comprehensive, prohibiting economic relations with an entire designated country, or they may be targeted specifically against particular groups, 
individuals, or industries (Masters, 2017). Haass (1998) further noted that sanctions designed to alter political and/or military behavior may take varied forms: arms embargoes, foreign assistance reductions and cut-offs, export and import limitations, asset freezes, tariff increases, revocation of most favored nation (MFN) trade status, negative votes in international financial institutions, withdrawal of diplomatic relations, visa denials, cancellation of air links, and prohibitions on credit, financing, and investment.

While policy is shaped by the president through discussions with his Cabinet advisors, particularly the Secretaries of State, Commerce, and Treasury, and often the mandate of international organizations, such as the UN, the State Department's Office of Economic Sanctions Policy and Implementation (SPI) is responsible for "developing and implementing foreign policy-related sanctions adopted to counter threats to national security posed by particular activities and countries" (Office of the Spokesperson, US State Department, 2014a). SPI provides guidance to the Departments of Commerce and Treasury on sanctions implementation while seeking international support of sanctions.

The US government utilizes three primary offices to regulate the application of approved sanctions, the Treasury Department's Office of Foreign Assets Control (OFAC), the State Department's Directorate of Defense Trade Controls (DDTC), and the Commerce Department's Bureau of Industry and Security (BIS). OFAC is responsible for administering and enforcing economic and trade sanctions, while BIS develops export control policies. DDTC's focus is on International Traffic in Arms Regulations (ITAR).

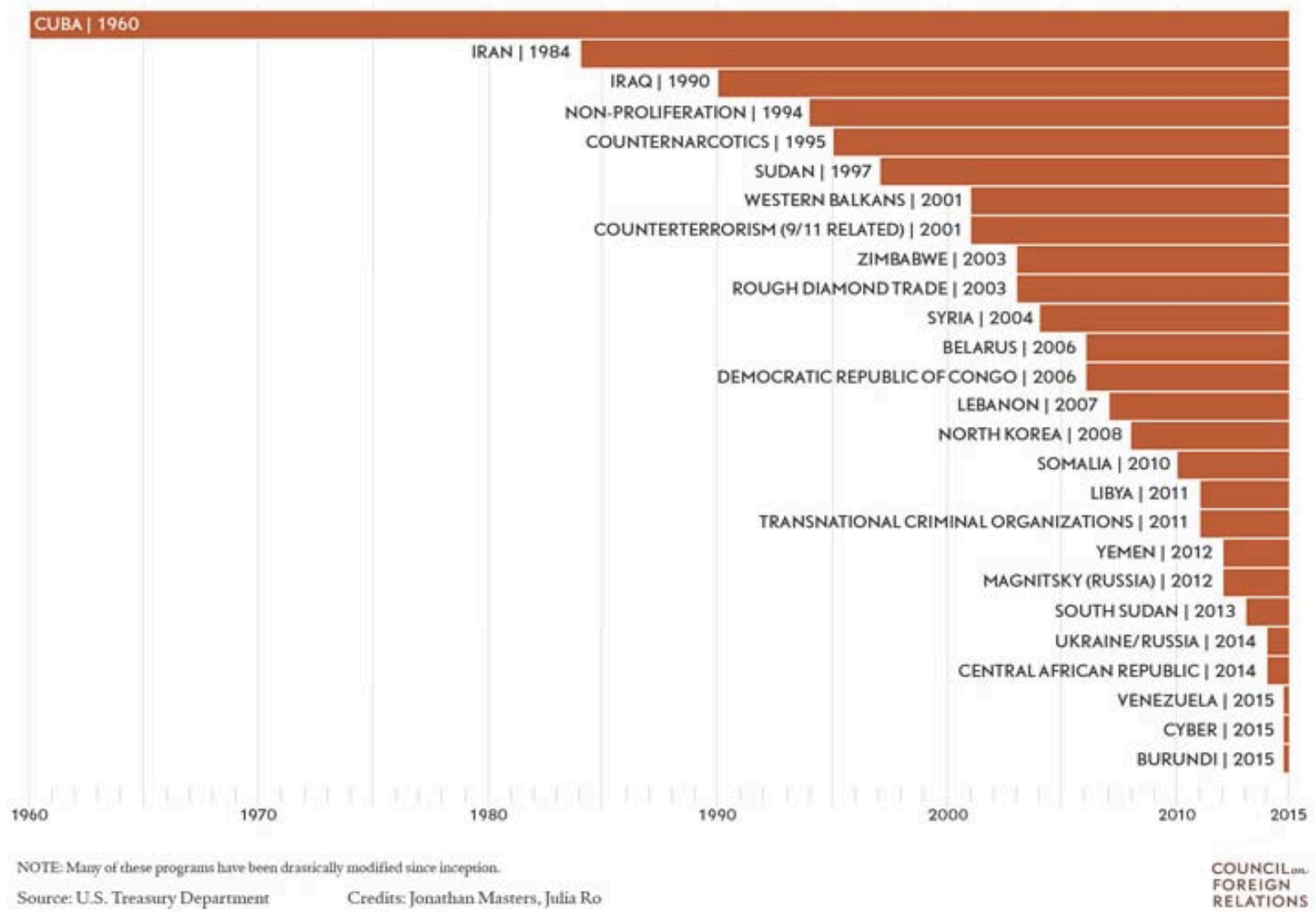

Figure 1. US sanction regimes (US Treasury Department via Council on Foreign Relations).

Though the framework for the application of economic sanctions is clearly structured within the US government, sanctions programs vary tremendously in scope. Trade prohibitions may be broad or narrow in 
focus and are applied to US companies, who may not directly or indirectly export or import goods, software, technology, or services to or from a sanctioned country. Sanctions further restrict investments and contracts. According to OFAC's list of Specially Designated Nationals (SDN) and Blocked Persons, there are approximately 5,500 current companies and individuals connected with sanctions targets. All US citizens and permanent resident aliens, regardless of where they are located, as well as all persons and entities within the US and all US incorporated entities and their foreign branches are required to comply with OFAC sanctions regulations (US Office of Foreign Asset Controls, 2018). OFAC is predominantly responsible for administering the 26 existing US sanctions programs currently in place. These include comprehensive sanctions regimes on Crimea, Cuba, Iran, North Korea, Sudan, and Syria, with the remainder of the economic sanctions being targeted sanctions against individuals and entities based upon criminal behavior or political crises. The below graph depicts US sanctions programs in effect through 2015.

While the administrative and enforcement mechanisms for economic sanctions are well mapped out, less clear is the mechanism for determining how and why to apply the sanctions. As discussed previously, sanctions may be applied by either the executive or legislature branches of the US government. Sanctions are viewed by the US government as a tool of foreign policy with which to compel specific behavior from the targets, while minimizing damage to US economic interests. Yet, tremendous controversy surrounds the determination of sanctions and subsequent application. While the goal, generally to compel a state or group to comply with established international norms, often is one reached by consensus within the government and international community, the decision to utilize economic sanctions vice another means of intervention stokes debate.

It must be established that economic sanctions are only one in a number of options available to the US government. Other such policy options include diplomatic negotiations, military intervention (ranging from the use of advisers and training staff to full-scale military operations); legal actions pursued through an international arbitrator, conditional aid, or even moral suasion that seeks to pressure, but not force, an actor into adhering to international norms. This latter option is often associated with the international community and an adherence to liberalist ideals of institutionalism, to include non-binding UN declarations as well as democratic indices, such as Freedom House, Polity IV, Transparency International, and Human Rights Watch.

\section{Literature Review}

Economic sanctions offer an alternative to military action to coerce a state actor, congruent to the classical international relations concepts of realism and liberalism. From the realist perspective, economic sanctions may be applied by a state actor when attempting to adjust the behavior of another state, as a tool to be utilized in great power competition in a calculation of materialistic and strategic gain and loss. States may employ unilateral sanctions seeking to diminish the relative power of a competitor by lessening their ability to enjoy economic advantages both at home and abroad. As Haass (1997) noted, the likely benefits to US foreign policy should be greater than the anticipated costs to both the US government and the US economy. This cost-benefit calculation should compare favorably to the expected consequences of all other foreign policy tools, to include military intervention, diplomacy, conditional aid, or even doing nothing (Haass, 1998).

The realist approach to sanctions would not consider the international norms at stake in the calculus. As such, this realist view would preclude involvement with and from the international community unless there was a demonstrable benefit of doing so.

While the US has shown no hesitation in enacting unilateral military action, it does exhibit a pattern of 
adhering to more of an institutional approach when evoking sanctions. For this paper, liberalism refers to the pursuit of a greater cause-the adherence to international norms, regardless or in spite of materialistic damages. With this definition, economic sanctions may also be considered a liberalist approach to altering state actions through the application or use of sanctions to shape behaviors. In this sense, sanctions would be discussed and agreed upon by the international community and then enacted by state actors. The path for this action is through an international organization, with the most impactful being the UN or the EU. In an effort to limit the scope of this paper, the focus will be limited to the UN when discussing liberalist norms in relation to international organizations.

The basis for UN sanctions is derived from the UN Charter (Chapter VII, Article 41), citing:

The Security Council may decide what measures not involving the use of armed force are to be employed to give effect to its decisions, and it may call upon the members of the UN to apply such measures. These may include complete or partial interruption of economic relations and of rail, sea, air, postal, telegraphic, radio, and other means of communication, and the severance of diplomatic relations. (United Nations Security Council [UNSC], 2013)

The UN employs sanctions through the Security Council, where sanctions resolutions must be approved by a majority vote of the fifteen member-council and no vetoes from a permanent member. UN sanctions are binding on all member states and are typically managed by a special committee and monitoring group. Yet, the UN has no independent means of enforcement (though Interpol does assist some sanctions committees), relying instead on member states. During the Cold War, sanctions were a rarity passed only against Southern Rhodesia (1968) and South Africa (1977). Rhodesia was targeted with comprehensive sanctions in response to the declaration of independence from the UK by the white minority regime; targeted sanctions on South Africa were due to the apartheid system, regional military aggression, and the pursuit of nuclear weapons. But since 1990, sanctions have been employed by the UN more than twenty times, primarily against parties in intrastate conflict, such as Liberia and Yugoslavia. While cooperation within the organization is increasing, there remains tension when differences arise between competing interests of major powers. Syria exemplifies this, as Russia and China have vetoed four Security Council resolutions since 2011 that sought to sanction the al-Assad regime due to human rights violations (UNSC, 2013). 


APPLICATION OF TARGETED UN SANCTIONS
Travel Ban Asset Freeze Arms Embargo Commodity
Interdiction
Somalia/Eritrea
Al-Q1/1907
Iraq 1518
Liberia 1521
DRC 1533
Côte d'lvoire 1572
Sudan 1591
Lebanon 1636
DPRK 1718
Iran 1737
Libya 1970
Taliban 1988
Guinea-Bissau 2048

Figure 2. UN sanctions (Security Council Report).

The Security Council has established principal objectives for the use of sanctions that fall within five categories: conflict resolution, non-proliferation, counter-terrorism, democratization, and the protection of civilians, to include human rights. Sanctions committees, responsible for the administration of sanctions, are established under Article 29 of the UN Charter and Rule 28 of the Provisional Rules of Procedure of the Security Council. Nearly, all sanctions imposed by the UN have corresponding committees, to include all sanctions currently enacted. These committees are responsible for monitoring, reporting, exemptions, and managing designation lists; the committee membership reflects that of the Security Council, with the chair being a permanent representative from one of the 10 elected member states. Decision-making within the committees is made on a consensus basis (UNSC, 2013).

Sanctions imposed by the UN have evolved from comprehensive sanctions against states to targeted sanctions; targets include diplomatic, travel ban, asset freeze, arms embargo, and commodity interdiction. The 13 active sanctions regimes include one or more of these; depicted in the below graph. Of interest, there are no current diplomatic sanctions, though historically this category has been frequently utilized.

While it is clear that economic sanctions are being used by both state actors (i.e., the US) and international organizations (i.e., the UN) as an alternative to violent action to coerce a state actor to adhere to established international norms, there is no standardized procedure for the application of sanctions. The previous discussion has clearly established that economic sanctions cover a broad spectrum of measures, both for the US and the UN. Comprehensive sanctions are being used less frequently due to questionable impact, with targeted sanctions being the preferred method of applying sanctions regimes. This is an important shift in sanctions 
policy and must be further examined.

Biersteker (2013) noted that fundamental questions must first be asked before a government or international organization can appropriately apply sanctions. These questions include:

1. What are the intended purposes?

2. What are the sanctions intended to achieve?

3. Are they trying to coerce a change in behavior?

4. Are they trying to constrain some party from having access to essential resources?

5 . Are they really trying to send a signal?

Once the purposes of sanctions are identified, it is critical to determine who and what the targets are, whether it is the government, leadership of the government, a faction in a conflict, or a terrorist group (Bierstaker, 2013). It is also at this stage that the actor imposing sanctions must determine political, economic, and moral implications for the imposition of costs on the designated actor. There is significant debate on both the viability and morality of sanctions, a debate that this paper will further address at a later point.

In order to first exemplify that challenges, costs, and opportunities presented by sanctions, this paper will examine specific case studies where sanctions were applied on either a comprehensive or targeted basis. Each case study will present an historical overview, discuss the policy debates held on the application of a sanctions regime in response to perceived violations of international norms, and examine the type, application, and enforcement of sanctions. The paper will further examine normative considerations for the sanctions imposed, including the implications of the sanctions regimes for innocent populations. The countries (Crimea, Iran, and South Africa) selected for case studies represent a diverse mix of sanctions regimes and were chosen based on several criteria to represent a broad spectrum of possible sanctions. These include: type of sanctions imposed, year imposed as well as duration of regimes, impact on targeted actors and populations, and involvement of the international community.

\section{Crimea}

The international community watched the growing Euromaidan protests in Kyiv in late 2013 with growing concern. Political tensions within Ukraine erupted following the country's sudden withdrawal from the Ukraine and EU Association Agreement in November 2013, largely attributed to pressure from Russia. In late January 2014, Secretary of State Kerry and Assistant Secretary of State Nuland were dispatched to meet European leaders to discuss the crisis. Nuland then traveled from Munich to Kyiv in early February to meet with government officials, opposition leaders, members of civil society, and business leaders, seeking to encourage agreement on a new government while planning for Ukraine's future. The Secretary of State's Office of the Spokesperson noted the goal was also to fulfill "the aspirations of the Ukrainian people for democracy, respect for human rights, European integration and economic growth” (Office of the Spokesperson, US State Department, 2014a). The next month witnessed escalating protests and violence; Ukrainian President Yanukovich fled to Russia on 25 February and the new government announced elections would be held in May.

Recognizing the interim government to be pro-Western, Russian President Vladimir Putin seized the opportunity to further exert influence in the region. Russian separatists became active in the East and Russia stoked tensions throughout the region. The Crimean peninsula was quickly flooded with Russian-speaking military men; Putin initially denied Russian involvement, suggesting the men belonged to local defense militias. It is widely accepted that they were Russian reservists with some active Russian elite special forces, known 
locally as zelonyye chelovechki (green men) or zelonyye lyudishki (little green men) (Haines, 2016). Crimea was effectively cut off from Ukraine by these pro-Russian soldiers and Spatsnaz units, who then took over the Supreme Council of Crimea, or Crimean Parliament.

The Russian involvement was alarming to US and European leaders, who responded with a flurry of diplomatic activity given the clear violations of Ukrainian territorial sovereignty and the Budapest Memorandum. Kerry called upon Russia to meet its obligations under the Memorandum, advising direct talks facilitated by the international community, and called for the deployment of international observers. The Obama administration, with the support of Congress, sought to avoid direct involvement while demonstrating resolve and commitment to international norms through diplomatic missions. Yet, these actions failed to deter Russia. On March 6, 2014, the Russian backed Crimean Parliament voted to join Russia and set a referendum to be held 10 days later. President Obama determined a bolder course of action to be necessary and issued Executive Order 13660. Citing the International Emergency Economic Powers Act (50 U.S.C. 1701), the National Emergencies Act (50 U.S.C. 1601), section 212(f) of the Immigration and Nationality Act of 1952 (8 U.S.C. 1182(f)), and section 301 of Title 3, United States Code, Executive Order 13660 stated:

I, Barack Obama, President of the US, find that the actions and policies of persons including persons who have asserted governmental authority in the Crimean region without the authorization of the Government of Ukraine that undermine democratic processes and institutions in Ukraine; threaten its peace, security, stability, sovereignty, and territorial integrity; and contribute to the misappropriation of its assets, constitute an unusual and extraordinary threat to the national security and foreign policy of the US, and I hereby declare a national emergency to deal with that threat.

The Executive Order instituted targeted sanctions against individuals involved, suspended entry into the US for those individuals, and prohibited donations, funds, and transactions with those persons, among other prohibitions (Executive Order 13660, 2014). In an effort to assist the beleaguered Ukrainian economy, the Commerce Department organized a Business Summit to facilitate US capital investment in Ukraine and aided development of the Innovation Council to accelerate entrepreneurship and develop a legal infrastructure for innovation. Exchange programs were also increased for Ukrainian students and young leaders (Office of the Spokesperson, US State Department, 2014b).

The leaders of the G-7 (now excluding Russia) made a joint announcement on 12 March stating that a Russian annexation of Crimea would violate: the UN Charter, Russia's commitments under the Helsinki Final Act, obligations under the 1997 Treaty of Friendship, Cooperation and Partnership, Russia-Ukraine 1997 Basing Agreement, and Commitments of the Budapest Memorandum. It further called on Russia to de-escalate in Crimea and other parts of Ukraine, urging the resolution of the crisis through the diplomatic processes (The White House, Office of the Press Secretary, 2014a). This announcement was of particular interest due to the solidarity of the G-7 leaders and the strong wording towards the Russian Federation actions. European leaders had previously been hesitant to take strong actions due to the economic ties with Russia; this statement made it clear that the West was united against the Russian actions in pursuit on international norms. The US affirmed concerns for the Ukrainian crisis at the UN's 25th Session of the Human Rights Council on 28 March, though gained no traction for UN sanctions due to the Russian veto power on the Security Council (Office of the Spokesperson, US State Department, 2014b). Given the lack of Russian response, instead, the Crimean referendum was used by the Russians to justify the annexation, the White House sought to impose further costs. A new Executive Order was signed that expanded targeted sanctions and created new authorities to target Russian government officials, with significant overlap to the sanctions released the following day by the EU 
(Executive Order 13661, 2014). On March 20, a third Executive Order was released, yet again expanding sanctions and aligning closely with the EU list; Bank Rossiya, known for providing services to senior Russian government officials, was also targeted (The White House, Office of the Press Secretary, 2014c).

The sanctions imposed in the Crimea case were a realization of liberalist ideals, the enforcement of international norms, and also realist concerns. In a zero-sum security dilemma, a gain in strategic interests for Russia would result in a loss for the West. Credibility of commitment was also at stake, thus one may also argue that the US instituted sanctions due to a realist cost-benefit calculation, while also adhering to liberalist principles. Yet, the EU sanctions adhered more closely to liberalist ideals, as the countries had a much stronger economic relationship with Russia. Until sanctions were applied, the EU was Russia’s largest trading partner and many EU states depended on Russia for vital oil and gas resources. Yet, their recognition of the violation of Ukraine's territorial sovereignty by Russia compelled action; though realists would further add that some of the states were motivated by concerns of an aggressive Russia emboldened by a lack of action and attempting similar territorial annexations elsewhere in Eastern Europe.

Economic sanctions were initially (first three executive orders) targeted towards specific individuals in Putin's inner circle, seeking a minimal impact on innocents. Targeted sanctions were applied to be deeply damaging to limited persons who held some level of responsibility for the annexation. Yet, there were some ethical concerns in the seizure or freezing of assets in that no notification or due process was rendered. Conversely, comprehensive sanctions have been determined to be harmful to broad populations of innocents and may in fact serve to strengthen a dictator's grasp of a regime, as exemplified in North Korea or Cuba. The sanctions instituted in Crimea initially were designed to avoid these concerns, reflecting on recent literature that indicates targeted sanctions to be more effective without harming innocents (Hufbauer, 2007). Weiss (1993, p. 499) noted that comprehensive sanctions targeting the former Yugoslavia, Iraq, and Haiti caused substantial suffering by vulnerable groups. Yet, President Obama chose to enact comprehensive sanctions against Crimea on December 19, 2014, blocking property of specified persons and prohibiting transactions with the Crimean region (Executive Order 13685, 2014). Justification for the comprehensive sanctions stemmed from the perceived lack of impact of the previous three EOs and Russia's continued assistance on the annexation.

One must also examine the broader impact of the sanctions in Crimea. Despite the decision to initially apply targeted sanctions, the immediate economic impact experienced by Russia was devastating-The Russian stock market declined nearly 15\% from 20 February to 17 March, with the ruble depreciating almost 3\% to the dollar (The White House, Office of the Press Secretary, 2014c). Russia’s GDP peaked in 2013 at just over \$2 trillion, dropping to $\$ 1.2$ trillion by May 2016 following a deep recession in 2015. Russian inflation reached 15.5\% in 2015 (Central Intelligence Agency [CIA], 2017). The international community had generally rallied around Ukraine, or at least did not support Russia. The March 2014 UN Security Council vote to declare the Crimean referendum illegal yielded 13 countries supporting the statement, with China abstaining in a break from its normal support of Russia. The EU and US applied similar economic sanctions and received support within their domestic populations.

Economic sanctions were supported by US military shows of force to include North Atlantic Treaty Organization (NATO) exercises and sending a guided missile destroyer to the Black Sea. While it is impossible to know with certainty the exact impact of sanctions versus other factors (particularly the massive drop in oil prices that also occurred during this period), there was clearly both a direct impact of applying sanctions as well as the indirect or secondary effects (i.e., third party countries hesitant to do business due to the US sanctions 
applied) felt by Russia. Targeted Russian leadership did not suffer the entirety of these economic impacts. The entire Russian population witnessed inflation and interest rates soar; their selection of imported goods from Europe dwindled. Crimeans faced dramatic economic challenges as their traditional sources of revenue, tourism and hosting the Black Sea Fleet, dropped precipitously. Ukraine restricted trade with the peninsula, causing a rise in prices for basic necessities. Crimean pensioners no longer received their pensions from the Ukrainian government, causing a loss in income before Russia agreed to resume payments. The economic costs imposed for Russia's decision to annex the Crimean peninsula impacted citizens in Russia and Crimea, innocents who had little to do with the annexation.

Yet, Russia retains control of the Crimea peninsula to this day. While the US applied significant targeted economic sanctions and later comprehensive sanctions, the objective of Russia respecting Ukrainian territorial sovereignty has not been met. This is despite the significant international response in support of international norms protecting territorial sovereignty, as supported by numerous treaty obligations committed to by Russia. Though the West rallied around Ukraine, infusing significant economic aid into a beleaguered economy, the impact of sanctions was ultimately limited. While the targeted sanctions may very well have halted further Russian action, they have been unsuccessful at achieving their stated goal. Moreover, the sanctions imposed had a far greater cost imposed on innocents, as the entire Russian and Crimean peoples paid a high economic price for the wayward actions of their leadership. Crimea highlights the challenge of targeted sanctions, despite carefully limiting sanctions and ultimately the sanctions reverberated through the Russian and Crimean economies with tremendous effect. The expansion of sanctions further ensured that those guilty of the violation of international norms-Putin and his close circle of advisors, would not be alone in shouldering the brunt of the costs imposed. While long-term costs are still unclear, there is no sign that sanctions will be lifted in the near future. The Crimean and Russian populations will continue to experience hardships, though there are signs that the sanctions are stimulating internal infrastructure to produce that which can no longer be acquired from abroad. This may result in a long-term improvement on both employment and availability of goods. Yet, Russia maintains a very high human development rating from the United Nations Development Programme (UNDP), with an upward trend from 1990-2015, with scores of 0.733-0.804, earning a rank of 48 in the world. Health outcomes for Russia in 2015 indicate life expectancy at 60 to be good at 18.4 years; similarly there are 43.1 physicians per 10,000 citizens. More than $94 \%$ have some secondary education and the unemployment rate in 2015 is 5.8\%. The perception of well-being (overall life satisfaction) is six on a scale of $0-10$, with 10 being most satisfied. Gender inequality is relatively low, at 0.271 or a rank of 52 . The domestic food price index is 4.3 with a volatility index of 5.2, indicating relative stability (UNDP, 2016). Overall, Russia performs in the upper tier on the human development index, indicating little significant impact from sanctions. Popular support for Putin has increased to more than $80 \%$ due to the "rally around the flag" effect, indicating that there are few drivers for Putin to reconsider his decision to annex Ukraine's sovereign territory despite the imposition of economic sanctions (Birnbaum, 2016).

\section{Iran}

The US has imposed various economic sanctions on Iran since 1979, following the seizure of the American embassy in Tehran. Carter imposed an escalating series of sanctions that began with banning Iranian oil imports and led to blocking all Iranian government assets in the US (worth approximately $\$ 12$ billion). By 1980, an embargo on US trade with Iran was in place, along with a travel ban. These initial sanctions were 
lifted following the 1981 hostage release, under the Algiers Declaration, but embargos were gradually re-imposed in the following years in response to violations of international norms. Following the 1983 when terrorist bombing of the Marine barracks in Lebanon, the Reagan administration imposed various restrictions as a result of Iranian state sponsorship of terrorist groups. These included opposition to World Bank loans to Iran as well as restrictions on dual-use technologies and Iranian imports.

In 1995, the Clinton administration banned all US participation in Iranian petroleum development and subsequently broadened sanctions to encompass a total trade and investment embargo, with bipartisan support. In 2005, the Bush administration issued a series of sanctions to freeze assets of firms and individuals believed to be involved in supporting terrorist groups, destabilizing Iraq, or furthering Iran's nuclear weapons program. In 2006, Iran, North Korea, and Syria Nonproliferation Act expanded the president's powers in the latter category. Sanctions to include enforcement were continued under the Obama administration, with sanctions applied for reasons as diverse as human rights abuses, drug trafficking, and nuclear proliferation.

In 2010, congress passed the Comprehensive Iran Sanctions, Accountability, and Divestment Act (CISADA) that further targeted refined petroleum products imported into Iran through non-US firms, as Iran relied on imports due to deficiencies with its own refineries. The Iran Threat Reduction and Syria Human Rights Act of 2012 authorized sanctions on those engaging in censorship in Iran as well as further targeting transport and insurance of Iranian oil. The FY2012 National Defense Authorization Act (NDAA) included even greater restrictions on foreign banks conducting transactions with the Iranian Central Bank. In 2013, congress passed the Iran Freedom and Counter-Proliferation Act to further extend sanctions to affect foreign firms operating in the transport or finance industries and supporting Iran's oil, automobile, or precious metal industries (OFAC, 2016a).

While initial US sanctions were unilateral, by the mid 2000s, Europe had joined the US in expressing concern for Iranian nuclear ambitions. Dual-use technologies were specifically sanctioned under UN resolutions 1696 and 1737, signed in 2006. Much like with North Korea, the UNSC made clear its objective to constrain the ability to develop nuclear weapons and ballistic missile technologies and compel a return to the international non-proliferation framework. The Iran sanctions regime has been strengthened three times, with resolutions 1747, 1803, and 1929 in response to dismal International Atomic Energy Agency (IAEA) reports. The UN maintained targeted sanctions against Iran in the form of a travel ban, asset freezing, and an arms embargo to compel adherence to international norms in regards to nuclear non-proliferation. Travel ban exemptions are granted on a case-by-case basis for humanitarian or religion grounds (United Nations, 2016).

This adherence to comprehensive and targeted sanctions represents a unique political consensus in that sanctions span six US presidential administrations and receive bipartisan support in the US and multilateral support abroad. Some success has been reached with Iranian sanctions. Many credit sanctions to be a factor in the 1981 hostage release. The impact of more recent sanctions on the Iranian economy gave a significant boost to presidential candidate Hassan Rouhani, who pledged to resume nuclear negotiations to achieve sanctions relief. The combined US and UN sanctions imposed in response to nonproliferation efforts by Iran were instrumental in Iran participating in the P5 +1 talks and the eventual agreement reached in the form of the Joint Comprehensive Plan of Action (JCPOA), finalized on 14 July 2015. On 16 January 2016, the IAEA certified that Iran had complied with nuclear dismantlement requirements, thus triggering the revocation of applicable Executive Orders and lifting of relevant (particularly secondary) US, UN, and EU sanctions (Katzman, 2016).

Economic sanctions are a defining pillar of US policy on Iran and have made a significant negative impact 
on the Iranian economy. In 1992, before Clinton era sanctions were announced, the US was Iran's sixth largest source of imports at $\$ 748$ million; by 2014, US exports to Iran had dwindled to $\$ 186.5$ million, mostly from food-particularly wheat. In 2015, the US imported only \$10 million worth of Iranian products. The Iranian rial declined more than 50\% post 2010 sanctions, which are widely attributed to causing Iran's recession. Inflation in Iran was estimated to be between 50-70\% from 2011-2013 due to the drop in currency value. The Iranian unemployment rate had reached nearly 20\% by 2014 (Katzman, 2016). Then, Treasury Secretary Jack Lew stated in 2015 that Iran's GDP was 15-20\% smaller than it would have been had post-2010 sanctions not been imposed. He further noted that US sanctions have cost Iran more than $\$ 160$ billion in oil revenue since 2012 (Lew, 2015). Humanitarian-related effects of sanctions were observed in several areas, particularly medicine with an inability to obtain Western-made medicines. Some of this was due to banks refusing to finance such sales, even if not restricted by sanctions. Pollution is another area of concern due to the impurities prevalent in Iranian refined products. The aviation sector is notoriously dangerous, with more than 1,700 killed in aviation accidents since the 1995 trade ban; this, however, is difficult to pinpoint entirely on the lack of parts availability (Katzman, 2016). The 2015 UN human development index notes a slightly positive trend for Iran from 1990-2015, with progression from a score of 0.572 to 0.774 , ranking 69 in the world with a high level. Life expectancy for Iranians at age of 60 years is 19.4 years; yet there are only 8.9 physicians per 10,000 citizens. Education levels are comparatively low, at $67.7 \%$ with some secondary education, though this likely reflects the high gender inequality (0.509 or a ranking of 118). Unemployment is high at $10.5 \%$ and food security is also a concern, with the domestic food price level index at 4.5 and volatility high at 13.0. Overall life satisfaction index is 4.7 (with 10 being most satisfied) (UNDP, 2016). It is likely that economic sanctions have impacted quality of life of Iranians within the government as well as innocents.

Within the US government, there lacks consensus on the specific objectives of sanctions. Under the Trump administration, targeted sanctions were re-imposed in Executive Orders 13382 and 13324 on 25 individuals and entities in response to a controversial ballistic missile test (The White House, Office of the Press Secretary, 2017). In March, the US imposed sanctions against 11 companies and individuals for technology transfers, sparking a counter sanction from Iran against 15 US companies for alleged human rights violations and cooperation with Israel (The White House, Office of the Press Secretary, 2017). The JCPOA specifically states that sanctions that were suspended or lifted shall not be re-imposed on other bases (i.e., terrorism or human rights). Both the Obama and Trump administrations made it clear that new sanctions to limit Iran's military power, human rights abuses, or support of terrorist groups may not violate the JCPOA. Congress has sought to extend the Iran Sanctions Act, inserting a provision into the FY2017 NDAA requiring a quarterly report to congress on the imposition of sanctions with respect to Iran's ballistic missile program (Katzman, 2016).

Economic sanctions imposed on Iran have been moderately successful in achieving limited aims. Sanctions imposed during the hostage crisis are largely attributed to the release of the American hostages. Those imposed with the support of the international community to expressly prevent the development of nuclear weapons have also attained a high degree of success, causing economic conditions that forced political leadership to negotiate with the P5 +1 countries. Yet, other sanctions imposed for state sponsored terrorism and human rights violations have largely been ineffective; Iran still actively does both. The suffering caused to Iranian citizens has been noteworthy. Though not as impacted as the Iraqi population, with hundreds of thousands of deaths attributed to comprehensive sanctions, the economic conditions of Iran have resulted in a 
degraded quality of life and pursuit of happiness.

\section{South Africa}

The application of economic sanctions on South Africa is a widely studied, and at times controversial, case in which the international community joined together to target an oppressive regime. The National Party came to power in 1948 and instituted decades of Apartheid rule. While the UN had imposed an arms embargo in the 1960s and again in 1977 following a massacre of schoolchildren in Soweto, the focus of this study will be on the significant sanctions applied in the 1980s due to the ongoing repression of apartheid. Reforms in early and mid 1980s to the governance of South Africa were slow and substantially less than the international community believed appropriate to meet international norms on basic human rights.

The economic siege on South Africa began in 1985, when Chase Manhattan Bank called in its loans due to pressure to sever ties with the apartheid regime; other American and European banks followed suit. In 1985, the European Economic Community imposed limited trade and financial sanctions on South Africa. The Reagan administration was initially opposed to sanctions, but enacted a limited export ban to avert stronger Congressional action. The political and financial crises that had gripped the country even prior to the institution of sanctions intensified and a second round of sanctions were enacted in 1986. Congress passes the Comprehensive Anti-Apartheid Act, over-riding the veto of President Reagan to enact severe restrictions in lending and import bans on iron, steel, coal, uranium, textiles, and agricultural products (Levy, 1999, p. 417). Yet, Reagan's veto speech alluded to the complexity of the decision, stating "Are we truly helping the black people of South Africa-the lifelong victims of apartheid, when we throw them out of work and leave them and their families jobless and hungry in those segregated townships? Or are we simply assuming a moral posture at the expense of people in whose name we presume to act." He likened sanctions to "declaring economic warfare on the people of South Africa" (Reagan, 1986). Instead, he called upon capitalism—the "natural enemy of such feudal institutions as apartheid" to not divest, but to increase investment. He noted a sugar import ban would imperil 23,000 black farmers; natural resource sanctions would impact up to 500,000 black miners. Yet, Reagan may have been focusing more on grand strategic concerns, however, given the struggles of the Cold War and the value of an ally controlling the Cape of Good Hope.

Reagan, however, was in the minority. While there were other critics, such as the Zulu-based Inkatha Freedom Party, who contended the main victims, would be destitute blacks who populated most of the country's nearly 50\% unemployment rate and most of the international community strongly supported the sanctions (Keller, 2013). The international community rallied against the oppressive apartheid regime, with few exceptions. Many state and local governments as well as universities in the US even enacted their own anti-apartheid statutes and divestments. Advocates argued that the impact on the white South Africans who were less accustomed to economic hardship were instrumental in success.

There is little dispute that economic sanctions were costly to South Africa, though studies question the exact impact. Hufbauer (2007, p. 246) noted that the annual cost of sanctions was approximately \$354 million, or $0.5 \%$ of gross national product (GNP). Trade restrictions were not applied on key industries like gold and diamonds. Exporters were able to find new markets in the East for many of their products. External loan finance and foreign investment, however, were particularly hard hit areas. By 1984 foreign loans were 70\% of total foreign liabilities, with foreign debt totaling more than \$23 billion in 1986 (Levy, 1999). Direct foreign investment in 1983 totaled \$17 billion. Between 1985 and 1987, US imports from South Africa declined 35\% 
(Knight, 1990). Yet, there were unexpected impacts as well, with the economic impacts spilling over to neighboring countries, including anti-apartheid countries, like Zambia and Zimbabwe. Isolated from world military suppliers, South Africa instead built its domestic armaments industry into a world leader. South African corporate giants flourished when American and European competitors divested, creating a vacuum in competition. The economic state turned over to the African National Congress (ANC) at successive elections was dismal (Keller, 2013).

The imposition of sanctions against South Africa saw substantial political gain achieved, without life-threatening suffering. The black majority population tended to be supportive of sanctions despite concerns that the population would be hard hit by unemployment (Weiss, 1993; Keller, 2013). In fact, this demographic ultimately faced improved employment opportunities due to import substitution. The 2015 UN human development index notes a slightly positive trend for South Africa from 1990-2015, with progression from a score of 0.621 to 0.666, ranking 119 in the world with a medium level. South Africa ranks on the multidimensional poverty index with $17.1 \%$ near multidimensional poverty and $1.3 \%$ have severe poverty. Life expectancy at 60 is 16.1 years old, with only 7.8 physicians per 10,000 people. Those with some secondary education include $74.9 \%$ of the population, but unemployment levels are very high at $25.1 \%$ in 2015 . Domestic food price level index is stable at 3, with a volatility index of 6.2. Overall life satisfaction is 4.9 (UNDP, 2016). These numbers indicate that the application and removal of economic sanctions may not have had a tremendous impact on South Africa, though it is difficult to determine with certainty as the UNDP human development index began only in 1990 .

While South Africa is often cited as an example of a successful application of economic sanctions, it has factors which make it unique. Sanctions were imposed multilaterally by the international community, not just the US. Many argue that Pretoria succumbed not due to international sanctions, but due to private businesses adjusting their calculations even beyond government mandated sanctions, particularly on new loans and investments. Hufbauer (2007) noted "economic sanctions can be credited with, at best, a modest contribution" towards the political transformation that took place in South Africa. Research indicates that the divestment by banks and investors, not mandated by sanctions, was the greatest factor in the regime conceding to international pressures. Social pressures, such as prohibition of South African participation in international competitions were also significant (Levy, 1999; Crawford \& Audie, 1999). Sanctions never completely isolated South Africa due to the ability to work through other, non-sanctioning companies and the lack of sanctions on "strategic" commodities (Crawford \& Audie, 1999, p. 12).

\section{Conclusion}

These case studies highlight broader questions of debate surrounding economic sanctions. Hufbauer, Jeffery, and Kimberly (1990, p. 2) at the Institute for International Economics pioneered a survey on the effectiveness of economic sanctions that determined an overall success rate of 34\% for 116 cases from 1914-1990. Pape (1997) questioned even this low success rate, reexamining the data around the "successful" sanctions and lowered the successes attributed to economic sanctions further to a paltry 4\%. This stems from the review that sanctions in and of themselves rarely brought forward desired changes (Weiss, 1993, p. 501). While in some cases, notably South Africa, as discussed previously, the contributions can be significant, others have a marginal impact, as seen in the first case study on Crimea. Yet, it is unquestionable that sanctions cause pain and suffering to innocents, ranging from justifiable as in South Africa to intolerable in Iraq (Weiss, 1993). 
It is this collection of secondary effects that tends to allude scholars. Economic data is well established and can provide insights into direct effects, but there lacks a concerted effort to also capture socio-demographic, socio-humanitarian and health data to quantify quality of life beyond the UNDP human development index.

Even with the ability to examine this data, one must also be mindful of the multitude of other factors that come to bear. Weiss (1993, p. 502) noted that three variables are relevant when determining civilian reactions to sanctions: The "rally round the flag" effect, where leaders use the shared sense of misery to broaden political support and demonize the sanctioning country; the government seizes the opportunity to condemn opponents and reward corrupt supporters by allocating scare resources; and whether sanctions increase or decrease the viability of political opposition or reform. All of these can be viewed in light of the Iranian case study, but elements of each were also present in Crimea and South Africa. Further, sanctions are known to cause both short-term suffering and longer-term structural damage to the economic and political systems. This can be captured when examining impacts on health, nutrition, basic infrastructure, and social services. Sanctions in Iraq have been found to have caused more deaths than military action in Operation Desert Storm (Weiss, 1993, p. 506). South Africa has suffered lingering effects from sanctions applied for years or perhaps even decades after sanctions were lifted. While humanitarian concerns often lead decision-makers to choose sanctions over military intervention, studies indicate that this rationale is in serious doubt (Pape, 1997; Weiss, 1993; Biersteker, 2013).

Invoking humanitarian suffering to coerce a long-term policy change (i.e., non-proliferation of nuclear weapons) may indeed cause more long term suffering and conflict. A 1999 study notes that post-Cold War sanctions may have caused more deaths than the use of weapons of mass destruction (Mueller \& Karl, 1999, p. 43). Indeed, Weiss (1993, p. 507) noted that "good feelings and self-congratulations have given way to less Pollyannaish notions about the pluses and minuses of economic and military coercion”. In this sense, one may argue that the use of sanctions is immoral, as the harm to innocents may never be justified. Indeed, the long-term suffering of sanctioned populations has been clearly documented. Rarely does this suffering inspire political reform internally (with the exception being South Africa), but instead often drives further political support to the authoritarian leadership as exemplified by Putin's rocketing approval figures after the Crimean annexation and subsequent application of sanctions.

There is another side of economic sanctions that tends to be overlooked-the impact on the country applying sanctions. Not only do sanctions reduce cooperation on broader interests (particularly for single issue disputes, such as drug-trafficking or nuclear proliferation) and have the potential to damage global US interests (as was Reagan's worry with the application of sanctions against the geo-strategic country of South Africa during the height of the Cold War), but there is a potential for significant economic damage at home. In 1995, sanctions reduced US exports to 26 targeted countries by an estimated \$15-19 billion, costing American workers more than 200,000 jobs (Hufbauer, 2007, p. 3). This is a significant economic impact without factoring secondary impacts-the loss of continuing sales and serve support, upgrades, replacement parts, et cetera. This can be viewed through the Iran case study, as even the lifting of sanctions will cause impacts within the US economy for years to come. Innocents are affected both in the targeted country and the country applying sanctions. These innocents have a voice through their elected officials in the US, and generally approved of sanctions in the case of South Africa, but often lack clarity of impact domestically and abroad.

Unilateral sanctions can put the sanctioning country at a distinct disadvantage, prohibiting US citizens from pursuing economic opportunities that Asian and European rivals are free to develop. American companies 
may be met with suspicion due to the proclivity of the US to apply unilateral sanctions, negatively affecting long-term growth. International companies may seek to minimize the use of US-made components to avoid a future sanctions problem, an issue particularly vivid in the technology and aircraft industry. Schaefer (1997) noted that the haphazard application of sanctions since the end of the Cold War has cost the US economy at least \$15 billion annually, while lacking clear foreign policy gains.

Targeted or "smart" sanctions have become more popular than comprehensive sanctions, largely due to the massive suffering invoked with the application of comprehensive sanctions. Cortright and George (2002, p. 22) argued, however, that smart sanctions have a smaller chance of success, as they tend to be more easily circumvented and carry less weight. This may explain the failure of the initial targeted Crimea sanctions and also why President Obama and the EU chose comprehensive sanctions in December 2014 (though also with little success in deterring Russia's annexation of the peninsula).

Another challenge with sanctions is the often uneven application of sanctions. A common complaint of unilateral sanctions is that they are not applied uniformly to all offenders. While the US sanctioned Iran for human rights abuses and pursuing nuclear weapons, no such sanctions were issued for Saudi Arabia for human rights abuses or Israel for nuclear weapons pursuits. This devalues the use of sanctions to uphold liberalist ideals and instead makes the application of unilateral sanctions reflect the strategic interests of a country, eroding the moralist arguments behind imposing sanctions.

This presents a moral dilemma if even targeted sanctions impose a massive humanitarian cost on innocents, should they be applied? But if sanctions are not used, what other foreign policy tools can be utilized to bridge diplomatic overtures and military action? Economic sanctions have long been looked at to fill the policy gap, with British Ambassador to the UN from 1998-2003 Sir Jeremy Greenstock perhaps summarizing it best, suggesting that the popularity of sanctions stems not from their effectiveness, but that "there is nothing else between words and military action if you want to bring pressure upon a government” (Marcus, 2010). This thinking has guided many who call for instituting multilateral sanctions on Syria. However, with a Russian veto certain on a UNSC vote, it is impossible to ensure true multilateral sanctions. Targeted sanctions could put pressure on leadership, but could also have an unintended consequence of further strengthening the reliance of al-Assad on Russian support and pushing Russia even further from embracing international norms. The Syrian people are already experiencing significant hardships and one would need a strong case for the type of multilateral, targeted sanction that could be applied without causing further harm to innocents.

Yet with the lack of strong evidence to support the effectiveness of sanctions, it is morally questionable to use them, particularly unilaterally. Unilateral sanctions rarely achieve the stated objectives and have measurable negative impacts on innocents. While they may lessen the risk of military intervention, this does not mean the suffering sustained by the population will be less, in fact, the suffering may be much greater over the long term. In this case, the means cannot be justified by the ends, as it is doubtful whether sanctions can successfully achieve the desired ends. Even the most successful of cases, commonly highlighted as South Africa, has tenuous ties linking sanctions to the end of the apartheid rule. The multitude of factors, including social sanctions and especially private divestment, indicate that economic sanctions were not the sole reason. In this sense, if one cannot prove with clarity that sanctions are effective, it is incumbent to reevaluate their usage. Conditional aid, moral suasion, and cooperative engagement are all viable foreign policy options that present a clearer moral argument. 
Sanctions can be more effective if administered multilaterally and with a clear, limited objective. Targeted sanctions should aim to impact as small a group as possible, ideally only those responsible for the violation of international norms. While the Crimea case indicates that this may not be effective in the long-run, it also provides a useful tool to effectively communicate intolerance of violations of international norms. If implemented properly, the impact on innocents is greatly reduced, though it will remain difficult to remove other economic factors (as is the case of the price of oil plummeting and depressing the Russian economy during the imposition of sanctions). The doctrine of double effect-permitting harm to innocent people as long as harm is not the specified intent, but proportional to the good sought to achieve has some merit. It is naïve to believe that sanctions may be applied without harm to innocents, as these case studies have demonstrated. Understanding the harm and working to limit it does make the use of sanctions morally permissible according to some; yet the evidence for the lack of ineffectiveness of sanctions makes this claim without validity. With Hufbauer and later Pape's studies demonstrating very low rates of effectiveness, it is clear that the application of unilateral and comprehensive economic sanctions should generally be precluded on the basis of both effectiveness and moral grounds. Similarly, multilateral sanctions should be limited in scope and used to enforce violations of international norms, not the pursuit of individual state interests. The effectiveness of economic sanctions as a moral tool of foreign policy is low. Indeed, it must be remembered that Pericles' first application of economic sanctions against Megara was a catalyst for the Peloponnesian War.

\section{Bibliography}

Andreas, P. (2005, June). Criminalizing consequences of sanctions. International Studies Quarterly, 49(2), 335-360.

Ang, A., \& Peksen, D. (2007). When do economic sanctions work? Political Research Quarterly, 60(1), 135-145.

Asgari, M., \& Reynolds, J. (2012). Iranians anxious over sanctions and mismanagement. BBC News, March 1.

Baldwin, D. A. (1985). Economic statecraft. Princeton, NJ: Princeton University Press.

Biersteker, T. J. (1993). Dealing with debt: International financial negotiations and adjustment bargaining: Case studies in international affairs. Boulder: Westview Press.

Biersteker, T. J. (2013). The art of sanctions. Brown Journal of World Affairs, 19(2), 11-17.

Birnbaum, M. (2016). How to understand Putin's jaw-droppingly high approval ratings? Retrieved from https://www. washingtonpost.com/world/europe/how-to-understand-putins-jaw-droppingly-high-approval-ratings/2016/03/05/17f5d8f2-d5 ba-11e5-a65b-587e721fb231_story.html?utm_term=.3ce70f254f6d

Central Intelligence Agency (CIA). (2017). World factbook. Retrieved from https://www.cia.gov/library/publications/the-worldfactbook /geos/rs.html

Cortright, D., \& George, L. (2002). Smart sanctions: Targeting economic statecraft. Lanham, MD: Rowaman \& Littlefield.

Crawford, N., \& Audie, K. (1999). How sanctions work: Lessons from South Africa. New York, NY: St. Martin's Press.

Doxey, M. P. (1996). International sanctions in contemporary perspective (2nd ed.). New York, NY: St. Martin's Press.

Edgar, R. E. (Ed.). (1990). Sanctioning apartheid. Trenton: Africa World Press.

Esriba-Folch, A., \& Wright, J. (2010). Dealing with tyranny: International sanctions and authoritarian rules. International Studies Quarterly, 54(2), 335-359.

Executive Order 13660. (2014). Blocking property of certain persons contributing to the situation in Ukraine. Federal Register, 79(46-56). Retrieved from https://www.federalregister.gov/documents/2014/03/10/2014-05323/blocking-property-ofcertain-persons-contributing-to-the-situation-in-ukraine

Haass, R. (1997). Sanctioning madness. Foreign Affairs, 76(6), 74-85.

Haass, R. (1998). Economic sanctions: Too much of a bad thing? Retrieved from https://www.brookings.edu/research/economicsanctions-too-much-of-a-bad-thing/

Haines, J. (2016). How, when, and why Russia will deploy little green men-and why the US cannot. Retrieved from https://www.fpri.org/article/2016/03/how-why-and-when-russia-will-deploy-little-green-men-and-why-the-us-cannot/ 
Hefti, C., \& Staehelin-Witt, E. (2008). Economic sanctions against South Africa and the importance of Switzerland. Retrieved from http://www.snf.ch/sitecollectiondocuments/nfp/nfp42p/nfp42p_staehelin-e.pdf

Hufbauer, G. C., Schott, J. J., Elliott, K. A., \& Oegg, B. (2007). Economic sanctions reconsidered (3rd ed.). Washington, DC: Peter Institute for International Economics.

Hufbauer, G. C., Jeffery, S., \& Kimberly, E (1990). Economic sanctions reconsidered: History and current policy (2nd ed.). Washington, DC: Institute for International Economics.

Kaempfer, W. H., James A. L., \& Anton D. L. (1987). Divestment, investment sanctions, and divestment: An evaluation of anti-apartheid policy instruments. International Organization, 41(3), 457-473.

Katzman, K. (2016). Iran sanctions. Washington, DC: Congressional Research Service. Retrieved from http://www.refworld.org/pdfid/58453dfb4.pdf

Keller, B. (2013). South African sanctions may have worked: At a price. Retrieved from http://www.nytimes.com/1993/09/12/ weekinreview/the-world-south-africa-sanctions-may-have-worked-at-a-price.html

Klotz, A. (1995). Norms in international relations: The struggle against apartheid. London: Cornell University Press.

Knight, R. (1990). Sanctioning apartheid. Trenton NJ: Africa World Press.

Levy, P. I. (1999). Sanctions on South Africa: What did they do? The American Economic Review, 89(2), 415-420.

Lew, J. (2015). Remarks at the Washington Institute for Near East policy 30th anniversary Gala. Retrieved from https://www. treasury.gov/press-center/press-releases/Pages/j10040.aspx

Lowenberg, A. D., \& William H. K. (1998). The origins and demise of South African apartheid. Ann Arbor: The University of Michigan Press.

Martin, L. (1992). Coercive cooperation. Princeton, NJ: Princeton University Press.

Marcus, J. (2010). Analysis: Do economic sanctions work? Retrieved from http://www.bbc.com/news/world-middle-east10742109

Masters, J. (2017). What are economic sanctions? Retrieved from http://www.cfr.org/sanctions/economic-sanctions/p36259

Minear, L. (1998). Morality of sanctions. In J. Moore (Ed.), Hard choices: Moral dilemmas in humanitarian intervention (pp. 229-250). Lanham, MD: Rowman \& Littlefield.

Mueller, J., \& Karl, M. (1999). Sanctions of mass destruction. Foreign Affairs, 78(3), 43-53.

Office of Foreign Assets Control. (2018, February). Mission. Retrieved from https://www.treasury.gov/about/organizational-structure/offices/Pages/Office-of-Foreign-Assets-Control.aspx

Office of Foreign Assets Control. (2016a, January). Iran sanctions. Retrieved from https://www.treasury.gov/resource-center/ sanctions/Programs/Pages/iran.aspx

Office of Foreign Assets Control. (2016b, June). Ukraine/Russia-related sanctions program. Retrieved from https://www.treasury. gov/resource-center/sanctions/Programs/Pages/ukraine.aspx

Office of the Spokesperson, US State Department. (2014a). Assistant secretary of State Victoria Nuland travel to Germany, Greece, Cyprus, Czech Republic, and Ukraine, January 31-February 6. Retrieved from https://2009-2017.state.gov/r/pa/prs/ ps/2014/01/221059.htm

Office of the Spokesperson, US State Department. (2014b). US/UK/Ukraine Press satement on the Budapest Memorandum Meeting. Retrieved from https://www.gov.uk/government/news/joint-statement-by-foreign-ministers-of-uk-us-and-ukraineon-budapest-memorandum

O’Sullivan, M. (2003). Shrewd sanctions: Statecraft and state sponsors of terrorism. Washington, DC: Brookings Institution Press.

Overseas Development Institute. (1986). Sanctions and the South African economy. Retrieved from https://www.odi.org/sites/ odi.org.uk/files/odi-assets/publications-opinion-files/6704.pdf

Pape, R. (1997). Why economic sanctions do not work. International Security, 22(2), 90-136.

Rodman, K. A. (1994). Public and private sanctions against South Africa. Political Science Quarterly, 109(2), 313-334.

Schaefer, B. (1997). A user's guide to economic sanctions. Retrieved from http://www.heritage.org/international-economies/ report/users-guide-economic-sanctions\#25

The White House, Office of the Press Secretary. (2014a). Statement of G-7 leaders on Ukraine. Retrieved from http://www.consilium.europa.eu/uedocs/cms_Data/docs/pressdata/en/ec/141460.pdf

The White House, Office of the Press Secretary. (2014b). Remarks by President Obama and Ukraine Prime Minister Yatsenyuk after Bilateral Meeting. Retrieved from https://obamawhitehouse.archives.gov/the-press-office/2014/03/12/remarkspresident-obama-and-ukraine-prime-minister-yatsenyuk-after-bilat 
The White House, Office of the Press Secretary. (2014c). Background briefing by senior administration officials on Ukraine. Retrieved from https://obamawhitehouse.archives.gov/the-press-office/2014/03/17/background-briefing-senior-administration-officials-ukrai ne

The White House. Office of the Press Secretary. (2017). Press briefing by press Secretary Sean Spicer \#8. Retrieved from https://www.whitehouse.gov/briefings-statements/press-briefing-press-secretary-sean-spicer-051217/

Tostenson, A., \& Bull, B. (2002, April). Are smart sanctions feasible? World Politics, 54, 373-403.

Treisman, D. (2016). Why Putin took Crimea: The gambler in the Kremlin. Foreign Affairs, 95(3), 47-54.

Tuzova, Y., \& Qayum, F. (2016, March). Global oil glut and sanctions: The impact on Putin’s Russia. Energy Policy, 90, 140-151.

United States Code Annotated (USCA). (2018). Title 50: War and national defense. Chapter 35: International emergency economic powers. Retrieved from https://www.treasury.gov/resource-center/sanctions/Documents/ieepa.pdf

US Congress. (2016). Public Law No: 114:277-Iran Sanctions Extension Act. Retrieved from https://www.congress.gov/114/ plaws/publ277/PLAW-114publ277.pdf

US Department of State. (2018). Iran sanctions. Retrieved from https://www.state.gov/e/eb/tfs/spi/iran/index.htm

United Nations Development Programme (UNDP). (2016). Human development report for 2016: Human development for everyone. Retrieved from http://hdr.undp.org/sites/default/files/2016_human_development_report.pdf

United Nations Security Council (UNSC). (2013). UN sanctions. Retrieved from http://www.securitycouncilreport.org/ atf/cf/\%7B65 BFCF9B-6D27-4E9C-8CD3-CF6E4FF96FF9\%7D/special_research_report_sanctions_2013.pdf

Weiss, T. G. (1993). Collective security in a changing world: A world peace foundation study of emerging global issues. Boulder, Colorado: Lynne Rienner Publishers.

Weiss, T. G., \& Thakur, R. C. (2010). Global governance and the UN: An unfinished journey: United Nations intellectual history project. Bloomington: Indiana University Press. 